\title{
AGRONOMIC PERFORMANCE AND GENETIC DIVERSITY AMONG LINES AND SOYBEAN CULTIVARS
}

\author{
DESEMPENHO AGRONÔMICO E DIVERSIDADE GENÉTICA EM LINHAGENS E \\ CULTIVARES DE SOJA
}

\section{Beliza Queiroz Vieira MACHADO'; Ana Paula Oliveira NOGUEIRA²; Osvaldo Toshiyuki HAMAWAKI ${ }^{3}$; Gabriel Lemes JORGE ${ }^{4}$; Gabriel Fernandes REZENDE ${ }^{4}$; Jacqueline Siqueira GLASENAPP ${ }^{5}$; Raphael Lemes HAMAWAKI ${ }^{6}$; Cristiane Divina Lemes HAMAWAKI ${ }^{7}$}

1. Engenheira Agrônoma, mestre em Agronomia (Fitotecnia), beliza_queiroz@hotmail.com ; 2. Professora, Doutora, Instituto de Genética e Bioquímica, Universidade Federal de Uberlândia, Uberlândia, MG, Brasil; 3. Professor, Doutor, Instituto de Ciências Agrárias, Universidade Federal de Uberlândia, Uberlândia, MG, Brasil; 4. Mestrando em Agronomia (Fitotecnia), Programa de Pós Graduação em Agronomia, Universidade Federal de Uberlândia, Uberlândia, MG; 5. Pós doutoranda em Agronomia (Fitotecnia),

Programa de Pós Graduação em Agronomia, Universidade Federal de Uberlândia, Uberlândia, MG, Brasil; 6. Doutorando em Melhoramento de Plantas, Southern Illinois University Carbondale, Illinois, EUA; 7. Doutoranda em Agronomia (Fitotecnia), Programa de Pós Graduação em Agronomia, Universidade Federal de Uberlândia, Uberlândia, MG, Brasil.

\begin{abstract}
Knowledge of genetic diversity is of great importance to the contribution of plant breeding, as it helps plant breeders to better selecting parents for establishment of segregating populations. This knowledge is especially important to crops that presents a narrow genetic base as soybean. The objective of this work was to assess agronomic performance and genetic diversity of lines and soybean cultivars, in order to find those ones with potential to be used as parents in breeding programs. Experiment was carried out during 2015/2016 season in the Federal University of Uberlândia farm known as Capim Branco. A randomized complete block designed was applied in order to assess twentythree morpho-agronomic features on twenty-four soybean genotypes. Significant genetic variability for all agronomic traits was found. Genotypes UFU B7, UFU B14, UFU B16, Msoy 6101 and UFUS 7910 were set as early maturity soybean, with life cycle duration ranging from 107.3 to 111 days. Genotypes UFU B1, UFU B3, UFU B8 and UFU B16 presented productivity values higher than national average of $2.870 \mathrm{~kg} \mathrm{ha}^{-1}$. Genotypes were clustered by UPGMA, Tocher and canonical variables methods. Both UPGMA and Tocher methods formed four groups. NDF was the major contributor to genetic diversity. Hybridizations between UFU B3, UFU B8, UFU B16 genotypes with UFU B1 genotype might be promising for establishment of segregating populations shown superior genetic variability. Under these circumstances, it was concluded that agronomic features assessed were useful on detection of parents with potential to UFU's soybean breeding program.
\end{abstract}

KEYWORDS: Glycine max. Hybridization. Parents. Genetic improvement.

\section{INTRODUCTION}

Soybean (Glycine max L. Merrill) have been originate in the Asian continent, precisely in the region of ancient China. This is the crop that in recent years most have increasingin area planted, which placed Brazil as second largest producer of this legume (RIGON et al., 2012). The country has being produced 95.43 million tons of grains in a cultivated area of 33.25 million hectares with average yield of $2.870 \mathrm{~kg} \mathrm{ha}^{-1}$ (CONAB, 2016).

Soy expansion over the Brazilian territory have being due, in great part, to soybean genetic improvement that have being developed new cultivars adapted to a range of edaphoclimatic conditions. Regarding to this, parent selection has proven to be the main step of a breeding process (BERTAN et al., 2007; PIMENTEL et al., 2013). In addition, genetic diversity studies based on agronomic traits, in particular quantitative characteristics, have been shown to be good tools for helping breeders choose the best parents (VILLELA et al., 2014).

Some studies have revealed that genetics base of Brazilian's soy is narrow; it means that it was originated from few lineages, which makes it especially difficult choosing the best parents for breeding programs (MIRANDA et al., 2007; PRIOLLI et al., 2010; WYSMIERSKI; VELLO, 2013). Wysmierski; Vello (2013) have evaluated the genetic diversity of 444 Brazilian soybean cultivars and have found 60 ancestors, of which only four contribute $55.26 \%$ of the genetic base.

Genetic diversity is useful as a tool on establishment of segregating populations; it might be assess by agronomic, morphological, molecular features or even coefficient of parentage, which allows the identification of the best parents in order 
to produce transgressive segregants (ODA et al., 2015; CRUZ et al., 2012).

Multivariate analyzes have being widely used in the study of genetic diversity. The most popular techniques are measures of dissimilarity, clustering methods, main components and canonical variables (CRUZ et al., 2011). This knowledge is quite useful on detecting genetic variation in breeding programs as it provides information about the degree of similarity or difference between two or more genotypes.

Usually dissimilarity measures as generalized Mahalanobis distance are complemented by agglomerative and hierarchical clustering methods. Tocher optimization has as criteria that average dissimilarity within each group must be less than the average distance between groups (RAO, 1962). Unweighted Pair Group Method with Arithmetic Mean (UPGMA) groups the genotypes by a process that repeats itself in several levels until a dendrogram is generated.

Addressing soybean genetic diversity in the State of Tocantins, Almeida et al. (2011) observed that clustering formed by the Tocher and UPGMA methods were quite similar regarding the formation of groups. Features as, number days to maturity, 100- grain weight and number of days to the blooming, contributed respectively with $39.49 \%$, $26.56 \%$ and $13.59 \%$ for the genetic dissimilarity found among soybean cultivars.

The primary objective of this work was to assess agronomic performance and genetic diversity of soybean genotypes developed by the Soybean Breeding Program of the Federal University of Uberlândia, in order to determine relative importance of those traits on soybean genetic divergence; aiming the selection of parents with a wide genetic diversity to be use on breeding programs.

\section{MATERIAL AND METHODS}

Experiment was carried out in the Federal University of Uberlândia farm, known as Capim Branco, in Uberlandia city on 2015/2016 season. Twenty-one lines developed by Federal University of Uberlândia Breeding Program plus three cultivars (UFUS 7910, UFUS Guarani and Msoy 6101) were evaluated in a randomized complete block design (DBC) with three replications.

Four lines of $5 \mathrm{~m}$ in length and spaced $0.5 \mathrm{~m}$ apart made up each experimental plot; the two central rows $0.5 \mathrm{~m}$ at the row endsformed the useful area, resulting in $4 \mathrm{~m}^{2}$ for each plot. Soil preparation was performed as conventional; with one plowing and two harrows. The chemical characteristics of the soil sampling from 0 to $20 \mathrm{~cm}$ depth, in Uberlandia were: 0.0 of $\mathrm{Al}^{3+}\left(\mathrm{cmol}_{\mathrm{c}} \mathrm{dm}^{-3}\right)$; 3.4 of $\mathrm{Ca}^{2+}\left(\mathrm{cmol}_{\mathrm{c}}\right.$ $\left.\mathrm{dm}^{-3}\right) ; 1.3$ of $\mathrm{Mg}^{2+}\left(\mathrm{cmol}_{\mathrm{c}} \mathrm{dm}^{-3}\right) ; 0.4$ of $\mathrm{K}^{+}\left(\mathrm{cmol}_{\mathrm{c}}\right.$ $\left.\mathrm{dm}^{-3}\right) ; 1.5$ of $\mathrm{H}^{+}$and $\mathrm{Al}^{+}\left(\mathrm{cmol}_{\mathrm{c}} \mathrm{dm}^{-3}\right) ; 16.6$ of $\mathrm{P} \mathrm{Meh}^{-}$ ${ }^{1}\left(\mathrm{mg} \mathrm{dm}^{-3}\right) ; 2.5$ of $\mathrm{MO}\left(\mathrm{dag} \mathrm{kg}^{-1}\right)$ and 6.2 of $\mathrm{pH}$ $\left(\mathrm{H}_{2} \mathrm{O}\right)$.

Before sowing, seeds were treated with fungicides CARBENDAZIM and TIRAM (Protreat ${ }^{\circledR}$ ) and then inoculated with two strains of the bacterium Bradyrhizobium japonicum. Manual sowing occurred in December 5, 2015 with 16 seeds per linear meter. Weed control was carried out by applying S-METOLACLORO (Dual Gold®) herbicide just after sowing and HALOXIFOPE-PMETHYL (Verdict ${ }^{\circledR} 20$ days after sowing.

Cobalt and molybdenum doses $\left(100 \mathrm{~mL} \mathrm{ha}^{-}\right.$ $\left.{ }^{1}\right)$ was applied on soybean seeds 30 days after emergence. In order to control Phakopsora pachyrhizi, applications with TRIFOXISTROBINA and PROTIOCONAZOL (Fox $\left.{ }^{\circledR}\right)$ in doses equal to $0.4 \mathrm{~L} \mathrm{ha}^{-1}$ were carried out. Pest control was performed when necessary with ACEFATO (Achero ${ }^{\circledR)}$ doses of $0.4 \quad \mathrm{~kg} \quad \mathrm{ha}^{-1}$; and TIAMETOXAM and LAMBDA-CIALOTRIN (Platinum Neo®) doses of $200 \mathrm{~mL} \mathrm{ha}^{-1}$.

In each useful plot, five soy plants were sampled randomly. Features was assessed by visual observations and measurements according stages of development as proposed by Fehr; Caviness (1977). Were evaluated, plant height at blooming (APF) and plant height at maturity (APM); number of nodes in the main stem at the blooming (NNF) and number of nodes on the main stem at maturity (NNM); number of days to the blooming (NDF) and number of days to maturity (NDM); number of pods with one grain (NV1), with two grains (NV2) and three grains (NV3); total number of pods per plant (NVT); average 100-grain weight (PCG) and grain yield $\left(\mathrm{kg} \mathrm{ha}^{-1}\right)$.

The obtained data were submitted to statistical analysis. To assess the genetic variability among genotypes a variance analysis was performed, adopting the $5 \%$ of probability level of significance. Subsequently, the averages were grouped using the Scott Knott test, at 5\% probability level.

Subsequently, the Tocher clustering methods (RAO, 1962) and the unweighted pair group with arithmetic mean, (UPGMA) were applied (CRUZ et al., 2012) using the Mahalanobis generalized distance $\left(\mathrm{D}^{2}\right)$ as dissimilarity measure. It was also used the Singh (1981) criterion to quantify the relative contribution of these traits to genetic divergence. Phenotypic residual variance and 
covariance matrices between features were used to assess the grouping pattern in a Cartesian plane, by canonical variable analyzes (CRUZ et al., 2011).

Computational Program in Genetics and Statistics software GENES (CRUZ, 2016) performed all steps of the described assessment.

\section{RESULTS AND DISCUSSION}

Significant genetic variability was found in all quantitative traits (Table 1) evaluated. This indicates possibility of genetic material selection aiming development of lineages. In a similar study, Almeida et al. (2011), Barros et al. (2016) and Cantelli et al. (2016) also found significant genetic divergence to most of the evaluated traits in soybean lines.
Coefficient of variation $(\mathrm{CV})$ ranged from $2.13 \%$ (NDM) to $56.50 \%$ (NV3). However, high $\mathrm{CV}$ values of production components features are acceptable under the conditions in which it was evaluated, because the environment (LEITE et al., 2015) great influences on quantitative traits. It was found that values obtained in this work were quite satisfactory when comparing to other studies of same plot type.

Because grain yield is a quite complex feature, being subject to a wide range of interferences, higher $\mathrm{CV}$ values are expected to such data coming from the experimental fields (SANTOS et al., 2011; DORNELES et al., 2011; LEITE et al., 2015; TEODORO et al., 2015; LEITE et al., 2016).

Table 1. Phenotypic variability, genetic parameters and coefficient of variation of morpho-agronomic characters in lines and cultivars of soybean planted in the city of Uberlândia-MG, 2015/2016 season.

\begin{tabular}{lll}
\hline Features & QMG & CV(\%) \\
\hline Plant height at blooming (APF) & $255.67 *$ & 9.71 \\
Plant height at maturity (APM) & $268.42 *$ & 7.15 \\
Number of nodes in the main stem at the blooming (NNF) & $6.06 *$ & 11.57 \\
Number of days to the blooming (NDF) & $96.15 *$ & 3.27 \\
Number of days to maturity (NDM) & $114.78^{*}$ & 2.13 \\
Grain yield per plant (PG) & $36.32 *$ & 38.79 \\
Number of nodes on the main stem at maturity (NNM) & $4.60 *$ & 4.49 \\
Number of branched nodes (NNR) & $10.26 *$ & 13.49 \\
Number of pods with one grain (NV1) & $5.68 *$ & 47.01 \\
Number of pods with two grain (NV2) & $191.06 *$ & 44.84 \\
Number of pods with theree grain (NV3) & $89.81 *$ & 56.50 \\
Total number of pods per plant (NVT) & $1277.49 *$ & 28.86 \\
Number of seeds per pod (NSV) & $0.074 *$ & 3.99 \\
Grain yield (kg ha ${ }^{-1}$ ) & $4349859.71 *$ & 29.76 \\
Average 100-grain weight (PCG) & $5.84 *$ & 8.61 \\
\hline
\end{tabular}

*: Significant at $5 \%$ significance level by the $\mathrm{F}$ test.

The features number of days for the blooming (NDF) and number of days for maturity (NDM) allowed separating the genotypes into five groups (Table 2). Shortest vegetative phase was found to UFUS 7910 with 45.3 days for blooming. Genotypes UFU B22 and UFUS Guarani presented vegetative phase of 65 days. These results are similar to that obtained by Unêda-Trevisoli et al. (2010); Pires et al. (2012); Cunha et al. (2013) and Ferreira Júnior et al. (2015).

Twenty-two days variation between the shorter cycle (UFUS 7910) and the longer cycle (UFU B2) genotypes was observed.UFU B7, UFU B14, UFU B16, Msoy6101 and UFUS 7910 were classified as early-cycle genotypes ranging from
107.3 to 111 days. By assessing soybean cultivars Cunha et al. (2013) have observed that Msoy 6101 reached its maturity within 109 days. That agrees with the results obtained in this work, were the same cultivar reached maturity with 110 days.

Currently, earlier cultivars are especially targeted by soybean breeding programs, since it has as advantage allowing a second crop in the same area, as the corn crop in the Cerrado. In addition, they are also being used as escape from diseases Asian rust reducing the number of fungicide applications to control this disease (SILVA et al., 2007; SILVA et al., 2014; UNÊDA-TREVISOLIet al., 2010). 
Table 2. Averages of six features evaluated in lines and cultivars of soybean cultivated in the city of Uberlândia-MG, 2015/2016 season.

\begin{tabular}{|c|c|c|c|c|c|c|c|c|c|c|c|c|}
\hline Genotypes & $\mathrm{NDF}$ & & NDM & & APF & & APM & & $\mathrm{NNF}$ & & NNM & \\
\hline UFU B1 & 59.3 & $\mathrm{~d}$ & 119.3 & $\mathrm{c}$ & 77.73 & $\mathrm{a}$ & 80.20 & $\mathrm{c}$ & 10.87 & $\mathrm{~b}$ & 18.13 & $\mathrm{a}$ \\
\hline UFU B2 & 61.7 & $\mathrm{~d}$ & 130.0 & $\mathrm{e}$ & 65.87 & $\mathrm{~b}$ & 79.13 & c & 10.20 & $\mathrm{~b}$ & 16.00 & $\mathrm{~b}$ \\
\hline UFU B3 & 59.0 & d & 119.0 & $\mathrm{c}$ & 72.00 & $\mathrm{a}$ & 90.30 & b & 12.80 & $\mathrm{a}$ & 17.70 & $\mathrm{a}$ \\
\hline UFU B4 & 62.5 & $\mathrm{e}$ & 125.5 & d & 75.80 & $\mathrm{a}$ & 94.00 & b & 10.20 & $\mathrm{~b}$ & 16.70 & $\mathrm{a}$ \\
\hline UFUS 7910 & 45.3 & $\mathrm{a}$ & 107.3 & $\mathrm{a}$ & 58.67 & $\mathrm{~b}$ & 88.87 & $\mathrm{~b}$ & 8.47 & $\mathrm{~b}$ & 15.20 & $\mathrm{c}$ \\
\hline UFU B6 & 56.5 & $\mathrm{c}$ & 125.0 & d & 64.30 & $\mathrm{~b}$ & 83.23 & $\mathrm{c}$ & 11.60 & $\mathrm{a}$ & 16.87 & $\mathrm{a}$ \\
\hline UFU B7 & 46.7 & $\mathrm{a}$ & 108.0 & $\mathrm{a}$ & 54.47 & $\mathrm{~b}$ & 88.50 & $\mathrm{~b}$ & 8.47 & $\mathrm{~b}$ & 18.50 & $\mathrm{a}$ \\
\hline UFU B8 & 60.6 & $\mathrm{~d}$ & 121.1 & $\mathrm{c}$ & 72.50 & $\mathrm{a}$ & 91.73 & $\mathrm{~b}$ & 13.90 & $\mathrm{a}$ & 17.80 & $\mathrm{a}$ \\
\hline UFU B9 & 55.3 & $\mathrm{c}$ & 119.0 & $\mathrm{c}$ & 80.20 & $\mathrm{a}$ & 97.67 & $\mathrm{a}$ & 12.47 & $\mathrm{a}$ & 18.20 & $\mathrm{a}$ \\
\hline UFU B10 & 55.7 & $\mathrm{c}$ & 123.0 & $\mathrm{~d}$ & 74.00 & $\mathrm{a}$ & 95.73 & $\mathrm{a}$ & 12.60 & $\mathrm{a}$ & 17.20 & $\mathrm{a}$ \\
\hline UFU B11 & 63.3 & $\mathrm{e}$ & 123.3 & $\mathrm{~d}$ & 86.87 & $\mathrm{a}$ & 100.27 & $\mathrm{a}$ & 11.47 & $\mathrm{a}$ & 17.57 & $\mathrm{a}$ \\
\hline UFU B12 & 54.0 & $\mathrm{c}$ & 123.5 & d & 64.30 & $\mathrm{~b}$ & 87.30 & $\mathrm{~b}$ & 9.30 & $\mathrm{~b}$ & 16.70 & $\mathrm{a}$ \\
\hline UFU B13 & 54.3 & $\mathrm{c}$ & 121.0 & $\mathrm{c}$ & 67.93 & $\mathrm{~b}$ & 88.20 & $\mathrm{~b}$ & 10.87 & $\mathrm{~b}$ & 18.27 & $\mathrm{a}$ \\
\hline UFU B14 & 49.0 & $\mathrm{~b}$ & 111.0 & $\mathrm{a}$ & 59.40 & $\mathrm{~b}$ & 75.07 & $\mathrm{c}$ & 10.27 & $\mathrm{~b}$ & 14.67 & $\mathrm{c}$ \\
\hline UFU B15 & 65.0 & $\mathrm{e}$ & 122.7 & $\mathrm{~d}$ & 83.80 & $\mathrm{a}$ & 100.37 & $\mathrm{a}$ & 11.67 & $\mathrm{a}$ & 17.73 & $\mathrm{a}$ \\
\hline UFU B16 & 51.0 & $\mathrm{~b}$ & 108.5 & $\mathrm{a}$ & 55.07 & $\mathrm{~b}$ & 65.00 & $\mathrm{~d}$ & 9.70 & $\mathrm{~b}$ & 14.60 & $\mathrm{c}$ \\
\hline UFU B17 & 56.5 & $\mathrm{c}$ & 115.0 & $\mathrm{~b}$ & 75.00 & $\mathrm{a}$ & 104.10 & $\mathrm{a}$ & 12.50 & $\mathrm{a}$ & 18.20 & $\mathrm{a}$ \\
\hline UFU B18 & 59.3 & $\mathrm{~d}$ & 125.3 & $\mathrm{~d}$ & 62.47 & $\mathrm{~b}$ & 79.23 & $\mathrm{c}$ & 9.67 & $\mathrm{~b}$ & 17.33 & $\mathrm{a}$ \\
\hline Msoy 6101 & 50.3 & $\mathrm{~b}$ & 110.0 & $\mathrm{a}$ & 54.67 & $\mathrm{~b}$ & 80.10 & $\mathrm{c}$ & 10.33 & $\mathrm{~b}$ & 14.53 & $\mathrm{c}$ \\
\hline UFU B20 & 54.3 & $\mathrm{c}$ & 123.0 & d & 63.87 & $\mathrm{~b}$ & 83.60 & $\mathrm{c}$ & 10.60 & $\mathrm{~b}$ & 17.40 & $\mathrm{a}$ \\
\hline UFU B21 & 55.0 & $\mathrm{c}$ & 116.5 & $\mathrm{c}$ & 77.20 & $\mathrm{a}$ & 100.23 & $\mathrm{a}$ & 10.90 & $\mathrm{~b}$ & 17.10 & $\mathrm{a}$ \\
\hline UFU B22 & 65.0 & $\mathrm{e}$ & 122.0 & $\mathrm{c}$ & 66.67 & $\mathrm{~b}$ & 79.00 & $\mathrm{c}$ & 12.73 & $\mathrm{a}$ & 18.13 & $\mathrm{a}$ \\
\hline UFUS Guarani & 65.0 & $\mathrm{e}$ & 121.0 & $\mathrm{c}$ & 73.30 & $\mathrm{a}$ & 84.27 & $\mathrm{c}$ & 12.50 & $\mathrm{a}$ & 18.00 & $\mathrm{a}$ \\
\hline UFU B24 & 54.0 & $\mathrm{c}$ & 118.5 & $\mathrm{c}$ & 77.30 & $\mathrm{a}$ & 92.90 & $\mathrm{~b}$ & 11.20 & $\mathrm{a}$ & 16.00 & $\mathrm{~b}$ \\
\hline Media & 56.6 & & 119.1 & & 69.30 & & 87.87 & & 11.05 & & 17.02 & \\
\hline
\end{tabular}

Averages followed by the same letter belong to the same group second Scott Knott test at 5\% probability.

Higher blooming and maturity plant heights were found at UFU B11 $(86.87 \mathrm{~cm})$ and UFU B17 $(104.10 \mathrm{~cm})$, respectively. Plant height at blooming and at maturity is very important trait, because it influences the plant lodging. Plants above $100 \mathrm{~cm}$ in height are inadequate because tend to lodge, which makes mechanized harvest difficult (NOGUEIRA et al., 2009; SEDIYAMA et al., 2015).

Hamawaki et al. (2010) have assessed agronomic performance of 24 soybean genotypes in the state of Minas Gerais, and have found an average of $86.80 \mathrm{~cm}$ to plant height at blooming, corroborating with results found in this work, where the average height of the 24 genotypes was 87.87 cm. However, Dorneles et al. (2011) and Selestino et al. (2014) observed values of plant height at maturity greater than $100 \mathrm{~cm}$.

Number of nodes in the main stem at blooming (NNF) ranged from 8.47 (UFUS 7910 and UFU B7) to 13.90 (UFU B8), while the number of nodes at maturity (NNM) ranged from 14.53 (Msoy 6101 ) to 18.27 (UFU B13). According to Sediyama et al. (2015) a soybean plant with high yield potential should have on average 17 to 18 nodes in the main stem; in this work only six genotypes having the number of nodes in the maturity below the recommended by this author were observed. However, Martins et al. (2011) observed a variation of 16.0 to 20.30 in the number of nodes at maturity in 15 cultivars evaluated in Santa Maria. Perini Júnior et al. (2012) have observedseven cultivars 
and have found values ranging from 12.03 to 16.61 for the same trait.

A soybean pod may contain up to five seeds, however most genotypes present pods with two or three seeds (MATSUO et al., 2015). Results found in this work show the predominance of pods with two grains for most of the genotypes (Table 3); corroborating with results obtained by Charlo et al. (2011) that when evaluating genotypes of vegetable soybean have verified a larger amounts of pods with two grains.

Total number of pods (NVT) is one of the most important components of soy yielding due to its correlation with productivity (ALCÂNTARA NETO et al., 2011; LEITE et al., 2016; VIANNA et al., 2013). According to Câmara (1998), a soybean plant can produce up to 400 pods, however on average the Brazilian cultivars presents from 30 to 80 pods per plant. NTV ranged from 45.10 (UFU B7) to 112.17 (UFU B22). Almeida et al. (2011), Charlo et al. (2011), Perini Júnior et al. (2012),
Cunha et al. (2013), Val et al. (2014) and Silva et al. (2014) have assessed agronomic performance of soybean cultivars and also obtained similar results.

Grain yield is one of the main traits to be considered in soybean breeding. There was a large amplitude in the averages of this feature (1495.4 to $5232.9 \mathrm{~kg}$ ha-1). Yielding of UFU B1, UFU B3, UFU B8 and UFU B16 genotypes were higher than others were, including the controls (UFUS 7910, Msoy 6101 and UFUS Guarani); which also had a grain yielding higher than the national average of $2.870 \mathrm{~kg} \mathrm{ha}^{-1}$.

Cunha et al. (2013) have evaluated the genetic variability among 79 soybean progenies and have found similar results with a grain yield variation of 1433.70 to $4393.59 \mathrm{~kg} \mathrm{ha}^{-1}$. Almeida et al. (2011); Dorneles et al. (2011); Pires et al. (2012); Ferreira Junioret al. (2015) and Marconato et al. (2015) also observed great oscillation between the grain yield of the evaluated genotypes.

Table 3. Averages of seven yield components evaluated soybean lines and cultivars in the city of UberlândiaMG, 2015/2016 season.

\begin{tabular}{|c|c|c|c|c|c|c|c|c|c|c|c|c|c|c|}
\hline Genotypes & NV1 & & NV2 & & NV3 & & NVT & & NSV & & PROD & & PCG & \\
\hline UFU B1 & 4.92 & $\mathrm{a}$ & 30.57 & $\mathrm{a}$ & 13.00 & $\mathrm{a}$ & 98.43 & $\mathrm{a}$ & 2.32 & b & 5020.6 & $\mathrm{a}$ & 12.53 & $\mathrm{a}$ \\
\hline UFU B2 & 3.25 & $\mathrm{a}$ & 16.20 & $\mathrm{~b}$ & 7.57 & $\mathrm{a}$ & 62.27 & $\mathrm{~b}$ & 2.28 & $\mathrm{~b}$ & 2081.8 & $\mathrm{~b}$ & 10.49 & b \\
\hline UFU B3 & 2.10 & b & 24.80 & $\mathrm{a}$ & 15.50 & a & 89.60 & $\mathrm{a}$ & 2.48 & $\mathrm{a}$ & 5232.9 & $\mathrm{a}$ & 11.60 & $\mathrm{a}$ \\
\hline UFU B4 & 0.90 & $\mathrm{~b}$ & 11.20 & $\mathrm{~b}$ & 10.30 & $\mathrm{a}$ & 60.70 & b & 2.59 & $\mathrm{a}$ & 2384.2 & $\mathrm{~b}$ & 11.99 & $\mathrm{a}$ \\
\hline UFUS 7910 & 3.60 & $\mathrm{a}$ & 17.20 & $\mathrm{~b}$ & 9.60 & $\mathrm{a}$ & 45.80 & $\mathrm{~b}$ & 2.27 & $\mathrm{~b}$ & 1757.9 & $\mathrm{~b}$ & 12.99 & $\mathrm{a}$ \\
\hline UFU B6 & 0.67 & $\mathrm{~b}$ & 21.10 & $\mathrm{a}$ & 19.28 & a & 90.33 & $\mathrm{a}$ & 2.58 & $\mathrm{a}$ & 3198.7 & $\mathrm{~b}$ & 12.41 & $\mathrm{a}$ \\
\hline UFU B7 & 3.03 & $\mathrm{a}$ & 8.78 & $\mathrm{~b}$ & 5.48 & $\mathrm{a}$ & 45.10 & $\mathrm{~b}$ & 2.36 & b & 1495.4 & $\mathrm{~b}$ & 13.37 & $\mathrm{a}$ \\
\hline UFU B8 & 3.77 & $\mathrm{a}$ & 25.08 & $\mathrm{a}$ & 24.10 & $\mathrm{a}$ & 99.23 & $\mathrm{a}$ & 2.49 & $\mathrm{a}$ & 4592.7 & $\mathrm{a}$ & 11.81 & $\mathrm{a}$ \\
\hline UFU B9 & 2.33 & $\mathrm{a}$ & 23.13 & $\mathrm{a}$ & 7.53 & $\mathrm{a}$ & 66.67 & $\mathrm{~b}$ & 2.33 & b & 1913.0 & $\mathrm{~b}$ & 11.64 & $\mathrm{a}$ \\
\hline UFU B10 & 2.33 & $\mathrm{a}$ & 14.00 & $\mathrm{~b}$ & 5.47 & $\mathrm{a}$ & 52.07 & $\mathrm{~b}$ & 2.31 & $\mathrm{~b}$ & 1734.8 & $\mathrm{~b}$ & 12.56 & $\mathrm{a}$ \\
\hline UFU B11 & 2.45 & $\mathrm{a}$ & 10.63 & $\mathrm{~b}$ & 11.30 & $\mathrm{a}$ & 74.90 & $\mathrm{a}$ & 2.59 & $\mathrm{a}$ & 1720.0 & $\mathrm{~b}$ & 10.33 & $\mathrm{~b}$ \\
\hline UFU B12 & 0.60 & b & 17.30 & $\mathrm{~b}$ & 9.80 & $\mathrm{a}$ & 50.40 & $\mathrm{~b}$ & 2.40 & $b$ & 1583.1 & $\mathrm{~b}$ & 10.17 & b \\
\hline UFU B13 & 1.25 & b & 23.97 & $\mathrm{a}$ & 12.70 & $\mathrm{a}$ & 69.87 & b & 2.40 & b & 2211.6 & b & 8.66 & $\mathrm{c}$ \\
\hline UFU B14 & 3.87 & $\mathrm{a}$ & 15.07 & $\mathrm{~b}$ & 22.80 & $\mathrm{a}$ & 93.13 & $\mathrm{a}$ & 2.49 & $\mathrm{a}$ & 1783.2 & $\mathrm{~b}$ & 10.73 & b \\
\hline UFU B15 & 1.53 & $\mathrm{~b}$ & 9.80 & $\mathrm{~b}$ & 10.88 & $\mathrm{a}$ & 61.73 & b & 2.56 & $\mathrm{a}$ & 1655.0 & $\mathrm{~b}$ & 10.23 & b \\
\hline UFU B16 & 3.10 & $\mathrm{a}$ & 20.30 & $\mathrm{a}$ & 18.80 & $\mathrm{a}$ & 98.00 & $\mathrm{a}$ & 2.58 & $\mathrm{a}$ & 4853.9 & a & 9.68 & $\mathrm{~b}$ \\
\hline UFU B17 & 1.00 & $\mathrm{~b}$ & 9.60 & $\mathrm{~b}$ & 8.70 & $\mathrm{a}$ & 51.50 & $\mathrm{~b}$ & 2.53 & $\mathrm{a}$ & 2018.2 & $\mathrm{~b}$ & 10.37 & b \\
\hline UFU B18 & 0.56 & b & 13.44 & $\mathrm{~b}$ & 16.49 & $\mathrm{a}$ & 53.87 & $\mathrm{~b}$ & 2.57 & $\mathrm{a}$ & 1589.2 & $\mathrm{~b}$ & 8.38 & $\mathrm{c}$ \\
\hline Msoy 6101 & 2.82 & $\mathrm{a}$ & 14.60 & $\mathrm{~b}$ & 14.37 & $\mathrm{a}$ & 80.37 & $\mathrm{a}$ & 2.54 & $\mathrm{a}$ & 2465.7 & b & 11.05 & b \\
\hline UFU B20 & 0.53 & b & 19.47 & b & 16.00 & $\mathrm{a}$ & 63.00 & $\mathrm{~b}$ & 2.48 & $\mathrm{a}$ & 3308.4 & $\mathrm{~b}$ & 10.13 & b \\
\hline UFU B21 & 0.62 & $\mathrm{~b}$ & 7.87 & $\mathrm{~b}$ & 13.50 & $\mathrm{a}$ & 55.60 & $\mathrm{~b}$ & 2.71 & $\mathrm{a}$ & 1592.2 & $\mathrm{~b}$ & 10.42 & b \\
\hline UFU B22 & 3.28 & $\mathrm{a}$ & 40.22 & $\mathrm{a}$ & 8.03 & $\mathrm{a}$ & 112.17 & $\mathrm{a}$ & 2.15 & $\mathrm{c}$ & 2015.0 & b & 8.21 & c \\
\hline UFUS Guarani & 2.97 & $\mathrm{a}$ & 29.97 & $\mathrm{a}$ & 7.18 & $\mathrm{a}$ & 85.00 & $\mathrm{a}$ & 2.23 & $\mathrm{c}$ & 2809.3 & $\mathrm{~b}$ & 10.59 & b \\
\hline UFU B24 & 4.90 & $\mathrm{a}$ & 14.90 & $\mathrm{~b}$ & 3.10 & $\mathrm{a}$ & 40.00 & $\mathrm{~b}$ & 2.10 & $\mathrm{c}$ & 1592.3 & $\mathrm{~b}$ & 11.77 & $\mathrm{a}$ \\
\hline
\end{tabular}

Averages followed by the same letter belong to the same group second Scott Knott test at $5 \%$ probability. 
100-grain weight is a very important factor to raise productivity. Rigon et al. (2012) have pointed a direct correlation between this trait and grain yield, reporting that it is possible to increase productivity gains by using PCG through indirect selection.

Variation of PCG ranged from 8.21 to 13.37 g. These values agree to those found by Cruz et al. (2010); Cunha et al. (2013); Silva et al. (2014) and Selestino et al. (2014), which indicated that there was great variation of this feature among the genotypes.

Dendrogram of the dissimilarity of the morpho-agronomic features of genotypes is shown in Figure 1. The co-phenotype correlation coefficient was 0.80 , which indicates that the graphical representation agrees with dissimilarities that have been found between pairs of genotypes.

A correlation coefficient equal or greater than 0.70 means a good fit between the graphical representation of the genetic distances and their original matrix (CRUZ et al., 2012). Thereby, the result obtained (0.80) was above the established limit, endorsing other works of divergence in the soybean crop (ALMEIDA et al., 2011; RIGON et al., 2012; SOUSA et al., 2015).

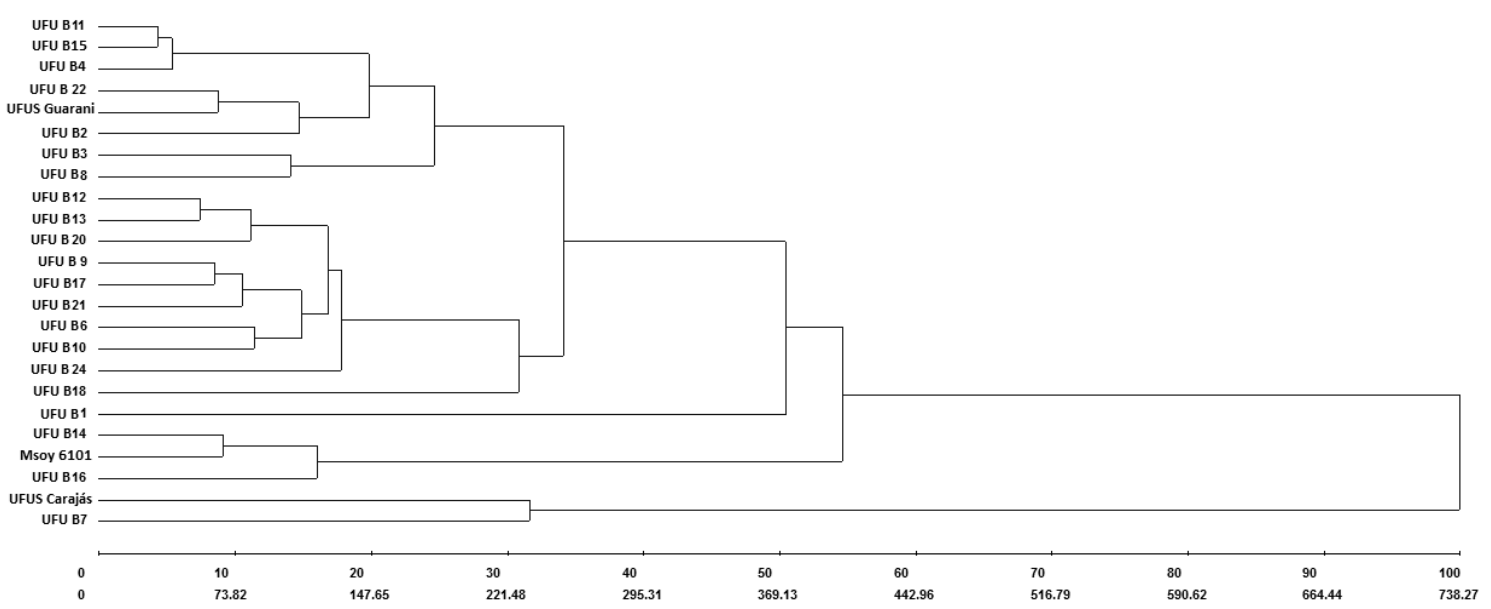

Figure 1. Dendrogram UPGMA of genetic dissimilarity among 24 soybean genotypes obtained using the generalized Mahalanobis matrix.

Delimitation of groups is usually subjective by observing points of high-level change in the dendrogram (CRUZ et al., 2012). Therefore, four distinct groups were found by using a cutoff point of $40 \%$ of dissimilarity as criteria in order to limit groups.

Lopes et al. (2014) used as a limit criterion $30 \%$ of dissimilarity as a cutoff point to genetic variability of oil yield of soybean cultivars. In addition, Sousa et al. (2015) observed eight groups by using a cutoff point of $43 \%$. Reina et al. (2014) defined the cutoff point in $52 \%$ of dissimilarity in the dendrogram, which separated the evaluated genotypes into six groups.

The application of the Tocher optimization method using Mahalanobis matrix split individuals within four groups (Table 4); 75\% of genotypes were included into group I, three genotypes into the group II (UFU B14, UFU B16, Msoy 6101), two into group III (UFUS 7910, UFU B7) and only one genotype (UFU B1) within group IV.

Table 4. Optimization cluster among 24 soybean genotypes, obtained by the Tocher method using generalized Mahalanobis distance.

\begin{tabular}{ll}
\hline Groups & Genotypes \\
\hline & UFU B2; UFU B3; UFU B4; UFU B6; UFU B8; UFU B9; UFU B10; UFU B11; UFU B12; UFU \\
& B13; UFU B15; UFU B17; UFU B18; UFU B20; UFU B21; UFU B22; UFUS Guarani; UFU B24 \\
II & UFU B14; UFU B16; Msoy 6101 \\
III & UFUS 7910; UFU B7 \\
IV & UFU B1 \\
\hline
\end{tabular}


It was found similar results regarding genetic divergence of 48 soybean genotypes studied by Santos et al. (2011). These authors observed a formation of four groups that included more than $60 \%$ of the analyzed genotypes into the first group. Sousa et al. (2015) also observed the inclusion of $63 \%$ of the genotypes into only one group.

Grouping of genotypes obtained by UPGMA and Tocher optimization methods were identical; corroborating with results obtained by Almeida et al.(2011), Reina et al. (2014), Peluzio et al. (2014) and Sousa et al. (2015), who also reported similarity between two methods.

UPGMA and Tocher grouping are the most commonly used methods regarding grouping of more similar genotypes. However, there are other methods including canonical variables. In this study, the first three canonical variables explained almost $80 \%$ of the total variance contained in the set of evaluated features. Therefore, it is possible satisfactorily access the observed variability among the genotypes and, under these circumstances, to interpret the phenomenon with considerable simplification through a two-dimensional graphical representation (CRUZ et al., 2012).

Dispersion of the genotypes by canonical analysis was graphically represented (Figure 2) in order to be compared to the groupings by the UPGMA and Tocher methods and evaluate the influence of each feature in the genetic diversity. Genotypes were clustered into seven distinct groups, which partially agreed to results obtained by the Tocher and UPGMA methods.

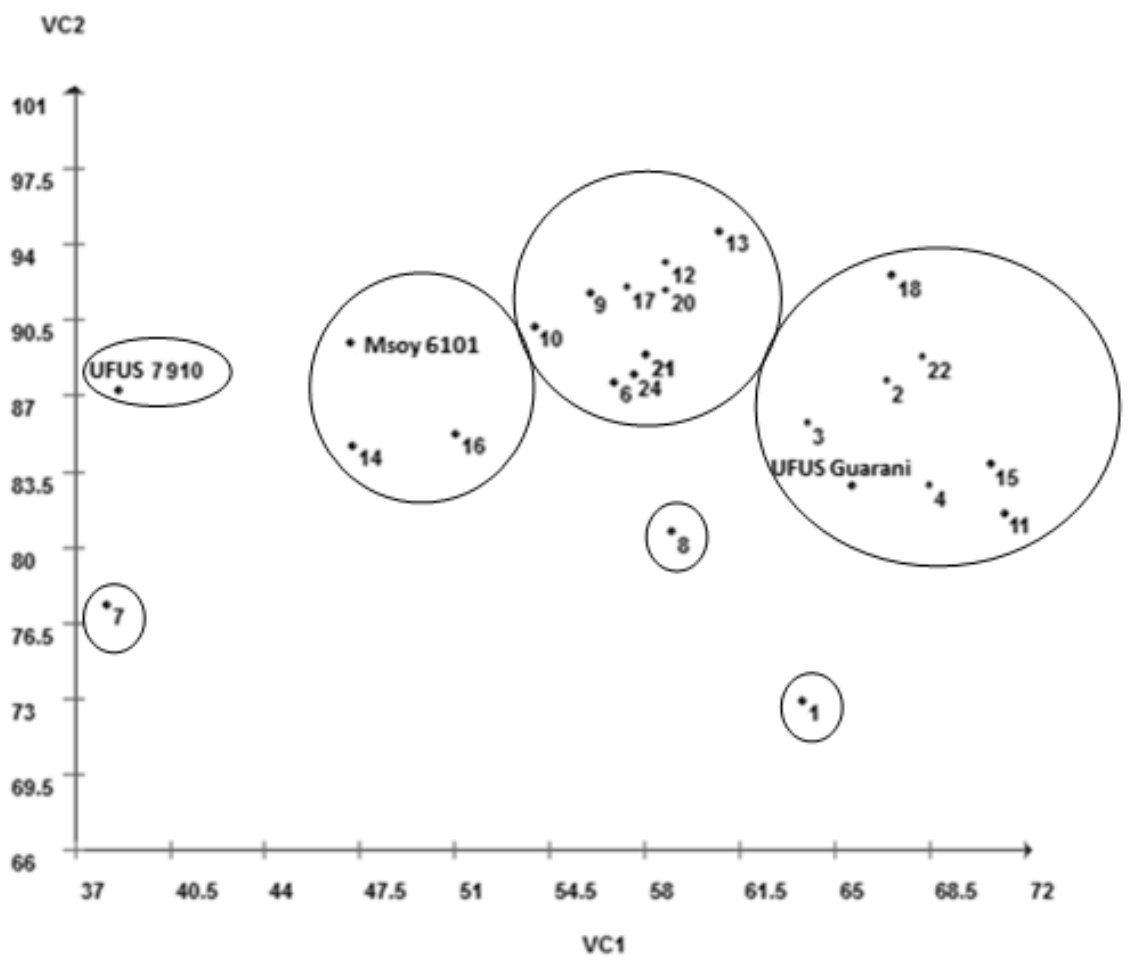

Figure 2. Graphic dispersion of 24 soybean genotypes regarding the first two canonical variables; established by the linear combination of morpho-agronomic traits. VC1: Canonical variable 1; VC2: Canonical variable 2.

In the study of genetic diversity agronomic characters of soy in the Tocantins State, Almeida et al. (2011) have found results which agreed regarding the identification of divergent genotypes by using either one of the methods, like Tocher, nearest neighbor methods or graphic dispersion of canonical variables. Peluzio et al. (2009) and Santos et al. (2011) also found similar results.

Evaluation of the genotypic differences through clustering studies such as UPGMA, Tocher and the canonical variables are quite useful to the breeder while choosing the best parents. The new hybrid combinations should be established based on the magnitude of their dissimilarities, as well as on the potential of the parents (ALMEIDA et al., 2011; REINA et al., 2014).

Relative contributions of each feature of the genetic divergence are shown in the Table 5 . Number of days for flowering was highlighted as the most important feature for the analysis, since it 
contributes with more than $48 \%$ to genetic divergence. Number of days to maturity (37\%) have remained in second place. These results are similar to those found by Almeida et al. (2011) and Rigon et al. (2012) which have observed that number of days to maturity contributed with 39 and $20 \%$ to genetic divergence between soybean genotypes, respectively. However, Peluzio et al. (2009), Peluzio et al. (2012) and Santos et al. (2011) found different results. Such studies showed contributions lower than $3 \%$ for NDM. Other features also presented estimates of relative contribution of small magnitude showing small expression in the genetic divergence.

Therefore, results established by Tocher, UPGMA and canonical variables allows the identification of the most promising crosses.

Table 5. Contribution relative of variables of 24 soybean genotypes, according to Singh (1981) criterion.

\begin{tabular}{lll}
\hline Variables & S.j. & Value (\%) \\
\hline Number of days to the blooming (NDF) & 900871.79 & 48.06 \\
Number of days to maturity (NDM) & 710841.53 & 37.92 \\
Plant height at blooming (APF) & 30367.42 & 1.62 \\
Number productive nodes (NNP) & 5205.39 & 0.27 \\
Average 100-grain weight (PCG) & 4996.17 & 0.26 \\
Number of seeds per pod (NSV) & 4190.13 & 0.22 \\
Grain yield (kg ha $^{-1}$ ) & 4151.14 & 0.22 \\
Number of nodes on the main stem at maturity (NNM) $_{\text {Number of pods with one grain (NV1) }}$ & 3681.15 & 0.19 \\
Total number of pods per plant (NVT) & 3638.24 & 0.19 \\
Plant height at maturity (APM) & 2623.74 & 0.14 \\
Number of branched nodes (NNR) & 1891.93 & 0.10 \\
Number of nodes in the main stem at the blooming (NNF) & 1684.53 & 0.08 \\
Number of pods with two grain (NV2) & 1408.26 & 0.07 \\
Number of pods with theree grain (NV3) & 610.63 & 0.03 \\
\hline
\end{tabular}

Promising hybridizations are UFU $\mathrm{B} 1 \mathrm{x}$ UFU B16; UFU B1 x UFU B8; UFU B8 x UFU B16; UFU B3 x UFU B16, since those cultivars were less similar between them and have presented high productivity averages. This means that when used for hybridizations in a breeding program, they will enable to enhance the number of desirable recombinants used as a source of higher genetic contributions.

\section{CONCLUSIONS}

Because of the existence of genetic variability, it was possible to identify dissimilar genotypes with higher average for the features studied.

Results obtained by Tocher, UPGMA and canonical variables were quite similar regarding to the identification of genetic diversity among soybean lines and cultivars, which helped to improve selection of divergent parents to agronomic traits.

UFU B16 genotype is the most recommended for hybridizations with divergent genotypes because it presents high productivity and precocity.

RESUMO: O conhecimento da diversidade genética é de grande importância para o melhoramento de plantas, pois auxiliam os melhoristas na escolha de genitores para formação de populações segregantes, especialmente na cultura da soja que é de base genética estreita. O objetivo do trabalho foi avaliar o desempenho agronômico e a diversidade genética de linhagens e cultivares de soja, com potencial de serem utilizados como genitores em programas de melhoramento genético. $\mathrm{O}$ experimento foi conduzido em uma área experimental localizada na Fazenda Capim Branco pertencente à Universidade Federal de Uberlândia na safra de 2015/2016. Foram avaliados 24 genótipos de soja, em delineamento de blocos completos casualizados, nos quais foram avaliados 23 caracteres morfo-agronômicos. Foi 
verificada variabilidade genética para todos os caracteres agronômicos. Os genótipos UFU B7, UFU B14, UFU B16, Msoy 6101 e UFUS 7910 foram classificados como genótipos de ciclo precoce, com duração variando de 107,3 a 111 dias. Os genótipos UFU B1, UFU B3, UFU B8 e UFU B16 apresentaram produtividade elevadas em relação aos demais com valores superiores à média nacional, que é de $2.870 \mathrm{~kg} \mathrm{ha}^{-1}$. Os genótipos foram agrupados pelos métodos UPGMA, Tocher e variáveis canônicas. Pelos métodos UPGMA e Tocher foram formados quatro grupos distintos. O NDF foi o caractere que mais contribuiu com a diversidade genética. Hibridações dos genótipos UFU B3, UFU B8 e UFU B16 com o genótipo UFU B1 são promissoras para obtenção de populações segregantes com variabilidade genética superior. Desse modo concluiu-se que o uso de caracteres agronômicos permitiu detectar genitores potenciais para o programa de melhoramento de soja da UFU.

PALAVRAS-CHAVE: Glycine max. Hibridação. Genitores. Melhoramento Genético.

\section{REFERENCES}

ALCÂNTARA NETO, F.; GRAVINA, G. A.; MONTEIRO, M. M. S.; MORAIS, F. B.; PETTER, F. A.; ALBUQUERQUE, J. A. A. Análise de trilha do rendimento de grãos de soja na microrregião do Alto Médio Gurguéia. Comunicata Scientiae, Bom Jesus, v. 2, n. 2, p. 107-112, 2011.

ALMEIDA, R. D.; PELUZIO, J. M.; AFFERRI, F. S. Divergência genética entre cultivares de soja, sob condições de várzea irrigada, no sul do Estado Tocantins. Revista Ciência Agronômica, Fortaleza, v. 42, n. 1, p. 108-115, 2011. http://dx.doi.org/10.1590/S1806-66902011000100014

BARROS, J. P. A.; SEDIYAMA, T.; SILVA, F. C. S.; SILVA, A. F.; BEZERRA, A. R. G.; ROSA, D. P.; SILVA, A. S. L.; OLIVEIRA, D. S. Estimates of genetic parameters and efficiency in selection for branching capacity in soybean genotypes. Journal of Agronomy, Falsalabad, v. 15, n. 1, p. 39-44, 2016. http://dx.doi.org/10.3923/ja.2016.39.44

BERTAN, I.; CARVALHO, F. I.; OLIVEIRA, A. C. Parental selection strategies in plant breeding programs. Journal of Crop Science and Biotechnology, Seoul, v. 10 n. 4, p. 211-222, 2007.

CAMÂRA, G. M. S. Soja: tecnologia da produção. Piracicaba: Publique, 1998, p. 293.

CANTELLI, D. A. V.; HAMAWAKI, O. T.; ROCHA, M. R.; NOGUEIRA, A. P. O; HAMAWAKI, R. L.; SOUSA, L. B.; HAMAWAKI, C. D. L. Analysis of the genetic divergence of soybean lines through hierarchical and Tocher optimization methods. Genetics and Molecular Research, Ribeirão Preto, v. 15, n. 4, p. 1-13, 2016. https://doi.org/10.4238/gmr.15048836

CHARLO, H. C. O.; PESSOA, R.; FUNICHELLO, M.; CASTOLDI, R.; BRAZ, L. T. Desempenho agronômico de dez linhagens de soja-hortaliça. Horticultura brasileira, Vitória da Conquista, v. 29, n. 3, p. 349-353, 2011. http://dx.doi.org/10.1590/S0102-05362011000300015

COMPANHIA NACIONAL DE ABASTECIMENTO - CONAB. Acompanhamento da safra brasileira: grãos: primeiro levantamento, outubro, 2016. Brasília: CONAB, 2016. Disponível em: http://www.conab.gov.br. Acesso em: 1 out. 2016.

CRUZ, C. D. Genes Software - extended and integrated with the R, Matlab and Selegen. Acta Scientiarum. Agronomy. Maringá, v. 38, n. 4, p. 547-552, 2016. http://dx.doi.org/10.4025/actasciagron.v38i3.32629

CRUZ, C. D.; FERREIRA, F. M.; PESSONI, L. A. Biometria aplicada ao estudo da diversidade genética. Visconde do Rio Branco, MG: Suprema, 2011, 620p.

CRUZ, C. D.; REGAZZI, A. J.; CARNEIRO, P. C. S. Modelos biométricos aplicados ao melhoramento genético. Viçosa, MG: UFV, 2012. v. 1, 514 p. 
CRUZ, T. V.; PEIXOTO, C. P.; MARTINS, M. C.; PEIXOTO, M. F. S. P. Componentes de produção de soja em diferentes épocas de semeadura, no oeste da Bahia. Bioscience Journal, Uberlândia, v. 26, n. 5, p. 709-716, 2010.

CUNHA, M. C. G.; HAMAWAKI, O. T.; SOUSA, L. B. Genetic variability among 79 soybean progenies from UFU breeding program. Bioscience Journal, Uberlândia, v. 29, n. 2, p. 340-349, 2013.

DORNELES, L. M. C.; REZENDE, D. F.; SOUSA, L. B.; HAMAWAKI, O. T. Diversidade genética entre linhagens de soja semiprecoce no município de Goiatuba - GO, safra 2009/2010. Revista Verde, Mossoró, v. 6, n. 1, p. 22-27, 2011.

FEHR, W. R.; CAVINESS, C. E. Stages of soybean development. Ames: Iowa State University 12p. (Iowa State University. Special Report 80), 1977.

FERREIRA JUNIOR, J. A.; UNÊDA-TREVISOLI, S. H.; ESPINDOLA, S. M. C. G.; VIANNA, V. F.; DI MAURO, A. O. Diversidade genética em linhagens avançadas de soja oriundas de cruzamentos biparentais, quádruplos e óctuplos. Revista Ciência Agronômica, Fortaleza, v. 46, n. 2, p. 339-351, 2015.

http://dx.doi.org/10.5935/1806-6690.20150013

HAMAWAKI, O. T.; SOUSA, L. B.; REZENDE, D. F.; HAMAWAKI, C. D. L. Yield and agronomic caracteristics of soybean breeding lines in Minas Gerais State, Brazil. Comunicata Scientiae, Bom Jesus, v. 1, n. 1, p. 43-47, 2010.

LEITE, W. S.; PAVAN, B. E.; MATOS FILHO, C. H. A.; ALCANTARA NETO, F.; OLIVEIRA, C. B.; FEITOSA, F. S. Estimativas de parâmetros genéticos, correlações e índices de seleção para seis caracteres agronômicos em linhagens F8 de soja. Comunicata Scientiae, Bom Jesus, v. 7, n. 3, p. 302-310, 2016.

LEITE, W. S.; PAVAN, B. E.; MATOS FILHO, C. H. A.; FEITOSA, F. S.; OLIVEIRA, C. B. Estimativas de parâmetros genéticos e correlações entre caracteres agronômicos em genótipos de soja. Nativa, Sinop, v. 3, n. 4, p. 241-245, 2015. http://dx.doi.org/10.14583/2318-7670.v03n04a03

LOPES, L. A.; PELUZIO, J. M.; AFFÉRRI, F. S.; CARVALHO, E. V. Variabilidade genética entre cultivares de soja, quanto ao rendimento de óleo, no estado do Tocantins. Comunicata Scientiae, Bom Jesus, v. 5, n. 3, p. 279-285, 2014.

MARCONATO, M. B.; PEREIRA, E. M.; SILVA, F. M.; BIZARIL, J. B.; MAURO, A. O.; UNÊDATREVISOLI, S. H. Genetic divergence in a soybean (Glycine max) diversity panel based on agromorphological traits. Genetics and Molecular Research, Ribeirão Preto, v. 15, n. 4, p. 1-10, 2015. http://dx.doi.org/10.4238/gmr15048980

MARTINS, J. D.; RADONS, S. Z.; STRECK, N. A.; KNIES, A. E.; CARLESSO, R. Plastocrono e número final de nós de cultivares de soja em função da época de semeadura. Ciência Rural, Santa Maria, v. 41, n. 6, p. 954-959, 2011. http://dx.doi.org/10.1590/S0103-84782011005000064

MATSUO, E.; FERREIRA, S. C.; SEDIYAMA, T. Botânica e Fenologia. In: SEDIYAMA, T.; SILVA, F.; BORÉM, A. (Ed) Soja: do plantio à colheita. UFV, Viçosa, 2015, p. 27-53.

MIRANDA, Z. F. S.; ARIAS, C. A. A.; PRETE, C. E. C.; KIIHL, R. A. S.; ALMEIDA, L. A.; TOLEDO, J. F. F.; DESTRO, D. Genetic characterization of ninety elite soybean cultivars using coefficient of parentage. Pesquisa Agropecuária Brasileira, Brasília, v. 42, n. 3, p. 363-369, 2007. http://dx.doi.org/10.1590/S0100204X2007000300009

NOGUEIRA, A. P. O.; SEDIYAMA, T.; BARROS, H. B. TEIXEIRA, R. C. Morfologia, crescimento e desenvolvimento. In: SEDIYAMA, T. (Ed). Tecnologias de produção e usos da soja. Londrina: Mecenas, 2009, 7-16p. 
ODA, M. C.; SEDIYAMA, T.; MATSUO, E. CRUZ, C. D.; BARROS, E. G.; FERREIRA, M. F. S. Phenotypic and molecular traits diversity in soybean launched in forty years of genetic breeding. Agronomy Science and Biotechnology, v. 1, n. 1p. 1 - 9, 2015.

PELUZIO, J. M.; LOPES, L. A.; CARVALHO, D. V.; AFFÉRRI, F. S.; DOTTO, M. A. Características agronômicas e divergência genética de cultivares de soja para percentagem de óleo nas sementes. Revista Ciências Agrárias, Recife, v. 57, n. 1, p. 1-8, 2014. http://dx.doi.org/10.4322/rca.2013.058

PELUZIO, J. M.; PIRES, L. P. M.; CANCELLIER, L. L.; AFFEÉRRI, F. S.; COLOMBO, G. A.; TEIXEIRA JUNIOR, T.; RIBEIRO, G. R. S. Genetic divergence among soybean cultivars in irrigated lowland in the State of Tocantins. Ciência Rural, Santa Maria, v. 42, n. 3, p. 395-400, 2012. http://dx.doi.org/10.1590/S010384782012000300002

PELUZIO, J. M.; VAZ-DE-MELO, A.; AFFÉRRI, F. S.; SILVA, R. R.; BARROS, H. B.; NASCIMENTO, I. R.; FIDELIS, R. R. Variabilidade genética entre cultivares de soja, sob diferentes condições edafoclimáticas. Pesquisa Aplicada e Agrotecnologia, Cascavel, v. 2 n. 3, p. 21-29, 2009.

PERINI JÚNIOR, L.; FONSECA JUNIOR, N. S.; DESTRO, D.; PRETE, C. E. C. Componentes da produção em cultivares de soja com crescimento determinado e indeterminado. Semina: Ciências Agrárias, Londrina, v. 33, suplemento, 1, p. 2531-2544, 2012. http://dx.doi.org/10.5433/1679-0359.2012v33Supl1p2531

PIMENTEL, A. J. B.; RIBEIRO, G.; SOUZA, M. A.; MOURA, L. M.; ASSIS, J. C.; MACHADO, J. C. Comparação de métodos de seleção de genitores e populações segregantes aplicados ao melhoramento de trigo. Bragantia, Campinas, v. 72, n. 2, p. 113-121, 2013. http://dx.doi.org/10.1590/S0006-87052013005000026

PIRES, L. P. M.; PELUZIO, J. M.; CANCELLIER, L. L.; RIBEIRO, G. R.; COLOMBO, G. A.; AFFÉRRI, F. S. Desempenho de genótipos de soja, cultivados na região centro-sul do estado do Tocantins, safra 2009/2010.

Bioscience Journal, Uberlândia, v. 28, n. 2, p. 214-223, 2012.

PRIOLLI, R. H. G.; PINHEIRO, J. B.; ZUCCHI, M. I.; BAJAY, M. M.; VELLO, N. A. Genetic diversity among brazilian soybean cultivars based on SSR loci and pedigree data. Brazilian Archives of Biology and Technology, Curitiba, v. 53, n. 3, p. 519-531, 2010. http://dx.doi.org/10.1590/S1516-89132010000300004

RAO, R. C. Advanced statistical methods in biometric research. New York: John Wiley, 1962. 390p.

REINA, E.; PELUZIO, J. M.; AFFÉRRI, F. S.; OLIVEIRA JUNIOR, W. P.; SIEBENEICHLER, S. C. Genetic divergence and phosphorus use efficiency in the soybean with a view to biodiesel production. Revista Ciência Agronômica, Fortaleza, v. 45, n. 2, p. 344-350, 2014. http://dx.doi.org/10.1590/S1806-66902014000200016

RIGON, J. P. G.; CAPUANI, S.; BRITO NETO, J. F.; ROSA, G. M.; WASTOWSKI, A. D.; RIGON, C. A. G. Dissimilaridade genética e análise de trilha de cultivares de soja avaliada por meio de descritores quantitativos. Revista Ceres, Viçosa, v. 59, n. 2, p. 233-240, 2012. http://dx.doi.org/10.1590/S0034-737X2012000200012

SANTOS, E. R.; BAROOS, H. B.; FERRAZ, R. C.; CELLA, A. J. S.; CAPONE, A.; SANTOS, A. F.; FIDELIS, R. R. Divergência entre genótipos de soja, cultivados em várzea irrigada. Revista Ceres, Viçosa, v. 58, n. 6, p. 755-764, 2011. http://dx.doi.org/10.1590/S0034-737X2011000600012

SEDIYAMA, T.; SILVA, F.; BORÉM, A. Soja: do plantio à colheita. Viçosa, MG: UFV, 2015, 333p.

SELESTINO, P. R.; UNÊDA-TREVISOLI, S. H.; SILVA, F. M.; PEREIRA, E. M.; VAL, B. H. P. Performance agronômica de genótipos precoces de soja destinados a áreas de reforma de canavial. Ciência e Tecnologia, Jaboticabal, v. 6, n. 1, p. 59-71, 2014. 
SILVA, A. F.; SEDIYAMA, T.; SILVA, F. C. S.; BEZERRAL, A. R. G.; FERREIRA, L. V. Correlation and path analsysis of soyben componentes. International Journal of Plant, Animal and Environmental Sciences, Foster City, v. 5, n. 1, p. 177-179, 2014.

SILVA, V. A. S.; JULIATTI, F. C.; SILVA, L. A. S. Interação entre resistência genética parcial e fungicidas no controle da ferrugem asiática da soja. Pesquisa Agropecuária Brasileira, Brasília, v. 42, n. 9, p.1261-1268, 2007. http://dx.doi.org/10.1590/S0100-204X2007000900007

SINGH, D. The relative importance of characteres affecting genetic divergence. The Indian Journal of Genetic Plant Breeding, New York, v. 41, n. 2, p. 237-245, 1981.

SOUSA, L. B.; HAMAWAKI, O. T.; BATISTA, R. O.; BERTAN, I.; NOGUEIRA, A. P. O.; ROMANATO, F. N.; HAMAWAKI, R. L. Genetic variability among soybean biparental crosses evaluated by multivariate analysis. Bioscience Journal, Uberlândia, v. 31, n. 5, p. 1404-1412, 2015. http://dx.doi.org/10.14393/BJv31n5a2015-26458

TEODORO, P. E.; RIBEIRO, L. P.; CORRÊA, C. C. G.; LUZ JUNIOR, R. A. A.; ZANUNCIO, A. S.; CAPRISTO, D. P.; TORRES, F. E. Path analysis in soybean genotypes as function of growth habit. Bioscience Journal, Uberlândia, v. 31, n. 3, p. 794-799, 2015. http://dx.doi.org/10.14393/BJ-v31n1a2015-26094

UNÊDA-TREVISOLI, S. H.; CARDOSO, G. K. R.; DI MAURO, A. O.; BLAT, S. F.; BARBARO, I. M.; PINHEIRO, J. B.; NASCIMENTO, A. F. Avaliação de cultivares de soja precoces para cultivo em áreas de reforma de cana-de-açúcar. Ciência e Tecnologia, Jaboticabal, v. 1, n. 1, p. 50-57, 2010.

VAL, B. H. P.; FERREIRA JUNIOR, J. A.; BIZARI, E. H.; DI MAURO, A. O.; UNÊDA-TREVISOLI, S. H. Diversidade genética de genótipos de soja por meio de caracteres agromorfológicos. Ciência e Tecnologia, Jaboticabal, v. 6, n. 1, p. 72-83, 2014.

VIANNA, V. F.; UNEDA-TREVISOLI, S. H.; DESIDERIO, J. A.; SANTIAGO, S.; CHARNAI, K.; FERREIRA JUNIOR, J. A.; FERRAUDO, A. S.; DI MAURO, A. O. The multivariate approach and influence of characters in selecting superior soybean genotypes. African Journal of Agricultural Research, v. 8, n. 30, p. 4162-4169, 2013.

VILLELA, O. T.; UNÊDA-TREVISOLI, S. H.; SILVA, F. M.; BARBARO JUNIOR, L. S.; DI MAURO, A. $\mathrm{O}$. Genetic divergence of roundup ready (RR) soybean cultivars estimated by phenotypic characteristics and molecular markers. African Journal of Biotechnology, Lagos, v. 13 n. 26, p. 2613-2625, 2014. http://dx.doi.org/10.5897/AJB2014.13661

WYSMIERSKI, P. T.; VELLO, N. A. The genetic base of Brazilian soybean cultivars: evolution over time and breeding implications. Genetics and Molecular Biology, Ribeirão Preto, v. 36, n. 4, p. 547-555, 2016. http://dx.doi.org/10.1590/S1415-47572013005000041 